\title{
TAX ADVANTAGES OF LOCAL BUDGETS AS AN INSTRUMENT OF FINANCIAL CAPACITY OF TERRITORIAL COMMUNITIES
}

\author{
Liudmyla Kozarezenko', Iryna Tochylina²
}

\begin{abstract}
Purpose. The article is devoted to the study of the structure of tax revenues of local budgets as an instrument of socio-economic development, analysis of the provision of local budgets by their own sources of income, revealing and substantiating directions for increasing the financial capacity of territorial communities. Methodology. Recommended by the Committee of Ministers to member states indicators of financial autonomy of local authorities are calculated and analysed for Ukraine in comparison with some European countries. A retrospective analysis of revenues of local budgets in Ukraine and the world in 2013-2017 was conducted. The tax base for property different from the land plot in 15 regions of Ukraine in 2013-2017 is investigated. Results. The significant predominance of transfers over tax revenues in the structure of local budget revenues was revealed. It is substantiated that the growth of own tax revenues of local budgets is directly related to the increase in the volume of income taxes on the property. It is proved that one of the most powerful instruments of the socioeconomic development of regions is projects taking into account the growth of taxes. It was revealed that the unwillingness to massive use of the latest financial instruments of economic development does not contribute to the dissemination of positive global experience in the development of regional infrastructure and expansion of the tax base. In Ukraine, the tax base of property tax is not related to the value of the property but depends on its size and area, which significantly differentiates the approach in other countries of the world. In view of this, local authorities, while ensuring the development of local infrastructure, should be interested in creating a new housing stock, timely putting it into operation, having in its structure a certain share of dwellings with large areas (which will increase the tax base) and business property. Practical implications. Potential property tax can be enhanced through the use of the method of tax increment financing that will enable finance local infrastructure by future revenues from this tax. Value/originality. According to the fact that Ukraine has no clear relationship between the level of development of local infrastructure and property tax revenues, but mainly evident dependence on the quantity and quality of housing and business development, job creation in the territory, it is advisable (during the preparation of institutional environment to attract financial and legal instruments for territorial development), methodologically we feel being right to satisfy not only gains tax revenues and property tax revenues and increased tax revenues per natural persons (due to the increase in the number of jobs) and a single tax (due to an increase in entrepreneurial activity in the region). The further use of this method of financing infrastructure projects and the possibility of its impact on regional tax base in Ukraine will require the development of guidance and methodological framework for the implementation of this method, including mechanisms for providing and transferring funds, method of calculation of future tax revenue guarantees for such projects to all interested stakeholders, Treasury services for such projects, etc.
\end{abstract}

Key words: tax revenues, local budget, financial decentralization, property tax, financial capacity of local communities, Tax Increment Financing.

JEL Classification: $\mathrm{H} 71, \mathrm{O} 23$

\section{Introduction}

Ukraine's implementation of the European integration course requires the reform of governance at the local level and the territorial organization of the government in accordance with the basic provisions of the European Charter of Local Self-Government. And the main task is to create an appropriate institutional environment for providing the local and delegated

\footnotetext{
Corresponding author:

${ }^{1}$ Kyiv National University of Trade and Economics, Ukraine.

E-mail: ljudmila.kozarezenko@gmail.com

${ }^{2}$ SESE "The Academy of Financial Management", Ukraine.

E-mail: tochilinaivgs@gmail.com
} 
authority to complete all the tasks. The expenditures of local budgets are the main source of financing for regional development and the factor of self-sufficiency of territories, and effective formation of own revenues of local budgets is one of the main preconditions for the socio-economic development of regions. Recent changes to the Budget and Tax Code of Ukraine are aimed at empowering local self-government bodies and giving them a greater autonomy in making decisions on budget revenues and expenditures. Also, these changes envisage the expansion of the revenue base of local budgets by consolidating them with stable tax revenues and encouraging communities to unify through the transition to direct intergovernmental fiscal relations with the state budget. In practice, the abovementioned transformations were implemented only partially, and the additional tax powers of local councils are limited to the present and are realized solely through the right to independently determine (with the limits) certain taxes and benefits from their payment.

\section{The assessment of fiscal decentralization level in countries with a transformational economy}

In the world practice, subsidizing local governments to the central government with a view to financial equalization is a prerequisite for fiscal decentralization and the creation of strong local self-government, as they are intended to contribute to economic stability and to ensure sustainable development. For example, in Greece,

Table 1

Indicators of fiscal decentralization level in some European countries in 2012

\begin{tabular}{|c|c|c|c|}
\hline Country & $\begin{array}{l}\text { The ratio } \\
\text { between } \\
\text { the local } \\
\text { authorities' tax } \\
\text { revenue and } \\
\text { the total tax } \\
\text { revenue for the } \\
\text { country, \% }\end{array}$ & $\begin{array}{l}\text { The ratio } \\
\text { between } \\
\text { the local tax } \\
\text { revenue and } \\
\text { the total local } \\
\text { revenue, \% }\end{array}$ & $\begin{array}{l}\text { The weight of } \\
\text { tax revenue } \\
\text { compared } \\
\text { to the weight } \\
\text { of grants, } \%\end{array}$ \\
\hline Greece & 6,85 & 61,72 & 0,11 \\
\hline The Netherlands & 9,42 & 70,59 & 0,13 \\
\hline Great Britain & 13,4 & 71,04 & 0,19 \\
\hline Ireland & 18,41 & 48,91 & 0,38 \\
\hline Hungary & 25,1 & 52,82 & 0,48 \\
\hline Luxembourg & 28,17 & 51,71 & 0,54 \\
\hline Denmark & 33,79 & 58,68 & 0,58 \\
\hline Poland & 31,69 & 48,53 & 0,65 \\
\hline Portugal & 33,27 & 29,89 & 1,11 \\
\hline Slovenia & 42,48 & 37,86 & 1,12 \\
\hline Czech Republic & 47,34 & 33,81 & 1,40 \\
\hline Finland & 45,35 & 30,73 & 1,48 \\
\hline France & 48,03 & 28,4 & 1,69 \\
\hline Sweden & 60,89 & 28,2 & 2,16 \\
\hline
\end{tabular}

Source: OECD Fiscal Decentralization Database the Netherlands, the UK, the low level of tax revenues is usually offset by transfers, which amount to 5-8 times the amount of tax revenues. In France, Finland, Sweden, on the contrary - tax revenues significantly exceed the amount of subsidies (Table 1).

In accordance with the European Union Recommendations on local taxation, financial equalization and subsidies to local authorities, the financial autonomy of local authorities is determined primarily by the availability of their own financial resources in those amounts that are sufficient to fulfil their obligations. The most important personal financial resources are tax revenues, which are subject to fiscal decentralization. In order to assess its level in the European Union, it is recommended to use the following indicators:

- the ratio between the local authorities' tax revenue level and the total tax revenue for the country;

- the ratio between the local tax revenue and the total local revenue;

- the weight of tax revenue compared to the weight of grants (both general and specific) from the state and other public authorities.

In the abovementioned Recommendations, the EU does not specify, which values of the abovementioned indicators characterize an adequate level of fiscal decentralization. However, if it still turns out to be low, governments are encouraged, together with local authorities, to develop measures that will enable them to increase their own share and distribution of tax revenues from local budgets without increasing the overall tax burden. For EU countries with a unitary state system, the values of these indicators are diverse, because they are largely dependent on the traditions of local self-government.

\section{Features of the reform of fiscal decentralization in Ukraine}

The analysis of fiscal decentralization level in Ukraine has allowed identifying trends that are opposite to the declared decentralization rate. The predominance of transfers over the volume of tax revenues of local budgets (almost halving in 2015) indicates a low level of provision of local communities with their own financial resources.

The share of tax revenues of local budgets was reduced by 2016. The ratio of tax revenues of local budgets to GDP in 2016 amounted to $6.2 \%$ (against 5\% in 2015 and $5.5 \%$ in 2014).

In the conditions of decentralization, this dynamics indicates a gradual strengthening of the tax base of local self-government bodies, but we believe that this is not enough to increase the financial autonomy of local budgets. Despite the financial decentralization that started and that involves the transfer of a part of tax revenues, transfers remain the largest source of local 
Table 2

Dynamics of indicators of fiscal decentralization in Ukraine in 2012-2017

\begin{tabular}{|l|c|c|c|c|c|c|}
\hline \multicolumn{1}{|c|}{ Indicators } & 2012 & 2013 & 2014 & 2015 & 2016 & 2017 \\
\hline $\begin{array}{l}\text { The ratio between the local authorities' tax revenue } \\
\text { and the total tax revenue for the country, \% }\end{array}$ & 23,81 & 25,76 & 23,76 & 19,35 & 22,57 & 24,27 \\
\hline $\begin{array}{l}\text { The ratio between the local tax revenue and the } \\
\text { total local revenue, \% }\end{array}$ & 38,11 & 41,26 & 37,69 & 33,36 & 40,12 & 40,03 \\
\hline $\begin{array}{l}\text { The weight of tax revenue compared to the weight } \\
\text { of grants, \% }\end{array}$ & 0,69 & 0,79 & 0,67 & 0,56 & 0,75 & 0,74 \\
\hline
\end{tabular}

Source: calculated according to the data of The Treasury of Ukraine

budget revenues from the state budget. And their share in total local budget revenues grew to the end of 2015 and already in the year 2016 amounted to 58\% (Figure 1).

Tax revenues are the second largest source of local budget revenues (33-43\%), the dynamics of which was negative for a long time. At the same time, the reduction of the share of trust funds and income from operations with capital testifies to the low economic activity of local selfgovernment bodies. In general, for the period from 2012 to 2016, the share of transfers increased by $23 \%$, while the share of tax revenues decreased by $1.7 \%$. This tendency does not correlate with the general purpose and basic principles of decentralization reform and points to the high dependence of local authorities on the Government.

A high proportion of intergovernmental transfers in the context of a significant increase in nominal volumes of tax revenues can be partly explained by the targeted deductions from the state budget in support of the development of territorial communities, which is the consequence of decentralization reform. It is anticipated that after the transition period is completed, local communities will be able to secure their financial obligations on their own (due to their own tax and non-tax revenues, attraction of credit funds under their guarantee, funds of special funds, etc.) and the need for additional grants from the central budget is minimized.

The structure of tax revenues of local budgets has undergone significant changes during the reform period. Thus, in comparison with 2013, the share of own tax revenues increased by $18 \%$, mainly due to the growth of income tax revenues (due to transfer to the local level of land tax and commercial property) and a single tax.

The main budget-forming local tax is the personal income tax, which accounted for 79 billion UAH in local budgets (up to 64.5 billion UAH in 2013, before the introduction of the new rules for the distribution of personal income tax between state and local budgets, 2014 - 62.5 billion, 2015 - 55 billion UAH) in 2016 . With the introduction of such rules, it might seem that due to the transfer to the state budget of a large share of

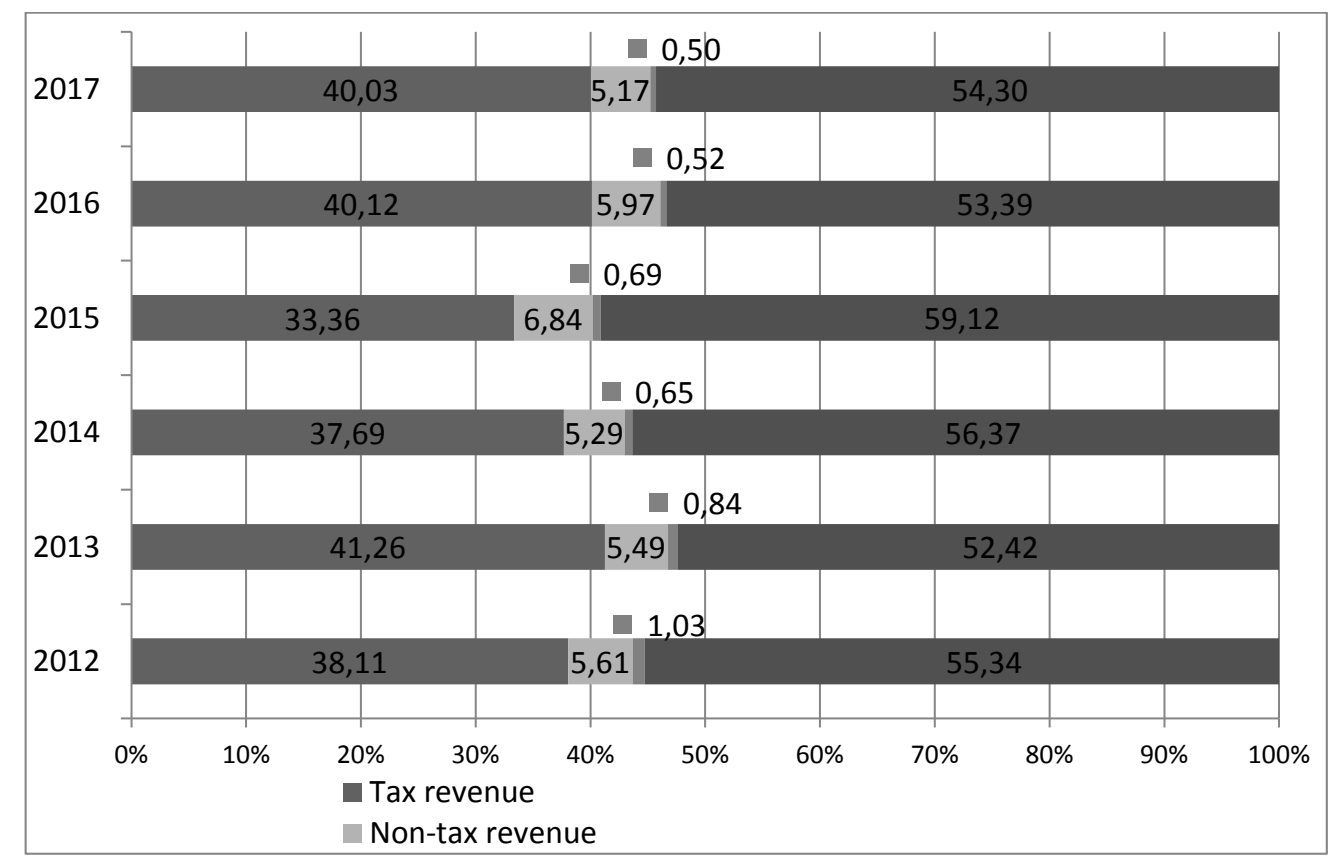

Figure 1. Structure of local budget revenues in Ukraine in 2012-2017

Source: Official site of The Treasury of Ukraine 
the personal income tax, local budgets suffer more losses than received additional resources. However, it should not be forgotten that after the formation of the united territorial communities, $60 \%$ of the personal income tax will be credited to their budgets, and 159 communities have already taken advantage of such a right in 2016. This fact, we believe, contributed to a substantial increase in the amount of income of this tax to local budgets. A new source of local revenues is the excise tax on the retail sale of excisable goods, and its share is $8 \%$ of tax revenues. In 2016 due to this tax received 11.6 billion UAH $-51.3 \%$ more than in 2015. However, its share increased only in economically active regions where there is a significant turnover of excisable goods. The ecological tax in the structure of tax revenues of local budgets, as well as on rent, accounts for about $1.5 \%$. These payments are aimed at regulating the use of natural resources and the ecological state of the territories and have a little fiscal significance. However, taking into account that in the OECD countries environmental taxes make up about $5 \%$ of total tax revenues, it can be argued that in Ukraine, the fiscal potential of environmental taxation is not fully realized today.

Despite the crisis in the economy, the volume of single tax receipts for small businesses continues to grow. In 2016, it was the second in terms of tax revenues and replenished local budgets by 17.2 billion UAH, which is $56 \%$ more than in 2015. Therefore, local authorities should be interested in creating conditions for the development of the entrepreneurial sector of the economy (including agricultural producers), which ensures the accumulation of the specified tax.

By 2015, the volume of revenues of the single tax prevailed in the structure of revenues of local budgets, and since 2016, the tax was deducted on the property, the terms of which have undergone significant changes to local budgets during the reform period. The general title "property tax" now combines payments that previously came to the state budget, namely: property tax, transport tax, and land payment. In general, an increase in the share of local taxes in the tax revenues of local budgets is directly related to the increase in income tax revenues, including the land payments addition that accounts for the largest share of property tax receipts. Thus, the share of property tax in 2016 amounted to almost $17 \%$ of tax revenues of local budgets, while by 2015 it was approaching zero.

\section{International experience of strengthening the financial capacity of territorial communities}

In the developed and transition economies, the property tax is used primarily to promote the economic development of territories through the targeted financing of the construction of local strategic objects (for example metro, redevelopment or rehabilitation of abandoned infrastructure or municipal objects). First of all, in these countries, the base of taxation of property tax depends on the value of the objects and the increase in its value leads to an increase in revenues to the corresponding budgets. Thus, the development of a settlement or district by improving infrastructure increases the attractiveness of this territory in terms of residence and business that contributes to the increase in the value of the property and, accordingly, the growth of tax revenues. Nevertheless, the development of urban infrastructure requires investment. Financing of infrastructure projects approved within a certain territorial community may be due to the future increase in property tax (as compared to the baseline, prior to the project implementation) and is called Tax Increment Financing (TIF) (Dye, Merriman, 2006). Thus, funds for covering the expenses necessary for the implementation of the project are covered from the local budget gradually (over 15-20 years) due to the growth of property tax revenues. In world practice, TIF projects are one of the most powerful socio-economic development tools available to local governments. This method is created for financial assistance to underdeveloped areas of settlements, which in other circumstances have no prospects for development. TIF projects can be initiated by local governments, local businesses or non-governmental organizations. Investors can act as private entities and in partnership with local authorities. Funds for the implementation of projects may be allocated in various proportions from the central budget (in the form of transfers or targeted grants), from the local budget, development funds, through the issuance of government debt obligations, from private sources or in the form of loans. Typically, local governments take on an administrative role by deciding how and where this financial instrument will be used. Thus, there is an opportunity to finance public or private projects, the guarantee of which is the future increase in revenues from property tax.

The functioning mechanism of TIF projects has its own peculiarities, but in general, it can be described as follows. For the territory within which the implementation of a particular infrastructure investment project is envisaged, the current (basic) amount of income from the property tax is determined. At the same time, it is assumed that improvements in infrastructure and external amenities will increase the revenue from property tax in the region. "Increase of taxes" will be considered only receipts from property tax exceeding the established basic amount. The growth of revenues from other taxes (value added tax/sales tax, income taxes due to the creation of additional jobs) is not taken into account in the calculations. During the project implementation period, the entire "tax increase" is directed to financing project costs or covering 
costs already incurred by the investor. An additional condition for financing the costs of implementing TIF projects may be the use of the matching funds (Dye, Merriman, 2006), according to which funding for the project is allocated after coordination between the central and local government (or between local government and business) and it is anticipated that when one party invests money, the other party allocates the same amount.

The use of this method of financing, like other types of borrowing, is associated with certain risks (Halvin, 2013; Stephens, Kille, 2015) and does not always produce the expected results. Implementation of such state support programs is associated with certain general risks. These include the following: firstly, the cost of the projects is transferred to the investor and taxpayers in the long run, and some of the future tax revenues are spent on repayment of interest on loans, becoming tax expense; secondly, in case of freezing the basic amount of income from property tax and directing its increase to the repayment of obligations under the development project, ignoring the fact of expanding the boundaries or increasing the population in the region, which entails an increasing need for public services financed from the budget; thirdly, the correct definition of project boundaries and the assessment of future tax increases some requires, for example, to take into account the inflationary increase in property prices, which would be a part of budget revenues even without project financing (Hardy, Lousyd, Tompagenet, 2016); fourthly, the increased attention of local authorities to areas where the implementation of development projects can disproportionate to the development of the region as a whole, contribute to the relative deterioration of the ration of conditions of the development of neighbouring regions, distortion of competitive conditions, the emergence of lobbying interests and risks of corruption abuses, etc.

\section{Sources of strengthening the financial capacity of territorial communities in Ukraine}

The property tax in Ukraine has a high potential because it takes into account both fiscal and social factors. But the problem is the inaccuracy of the data of the state cadastre of property (in particular, for individuals), which complicates the identification of the tax base and the collection of this tax in full. Therefore, without solving these problems, the property tax will continue to be symbolic in nature.

Although the nominal value of property tax from individuals increased substantially (from 0.09 billion UAH in 2012 to 97.43 billion UAH in 2017), it still accounts for less than $0.1 \%$ of local budget revenues, which not significantly affects the financial capacity of the regions. In addition, during the period of this tax operation, its tax base has significantly expanded due to raising the marginal rate of tax for property to $1.5 \%$ of the minimum wage per 1 sq. $\mathrm{m}$ of the total area of the residential and non-residential property, as well as an additional tax rate of 25 thousand UAH for apartments with an area of more than 300 sq. m and houses - more than 500 sq. m. Starting from 2015 , the tax base of the property tax is extended by including in commercial (non-residential) property taxes before taxation.

The distribution of income taxes on property shows that the lion's share of payments is provided by legal entities, although the income from individuals also gradually increases. For 2015-2017, the volumes and structure of income from property taxes have changed significantly but the analysis of data in the dynamics shows that the main attention should be paid to the potential of property taxes in the segment of individuals, as well as to improve the methodological basis for their calculation and collection, the formation of a single information base regarding the available housing stock for tax purposes.

In favour of the fact that local governments are not always able to determine what level of consolidation of the tax to local budgets can be, that is shown by the results of our sample survey. The local councils of 20 small towns of Ukraine sent inquiries about the volume and distribution of housing stock. Only individual city councils were able to provide an exhaustive answer; six city councils directly indicated that they had no data on available housing stock in the city. As a rule, information is available on the total area and number of apartments in multi-apartment buildings that are in communal ownership. Information on private sector housing stock is largely absent or incomplete. Since property tax rates are determined by the decision of a village, settlement or city council, in the event that such a decision is not adopted, taxes are subject to the application of minimum rates. Thus, if the village, town or city council has not determined the rates of property tax, the minimum rate of such a tax is $0 \%$.

In many regions of Ukraine, state programs for mobilizing local resources and attracting additional funds for the improvement, social infrastructure creation, etc. are implemented and actively used. Involving communities in solving regional problems contributes to the revitalization of business investment interests in the implementation of decentralization reforms. However, the immaturity of local selfgovernment and the unwillingness to make massive use of the latest financial instruments of economic development, including public-private partnerships, co-financing instruments, do not contribute to the spread of positive global experience in developing the regional infrastructure and expanding the tax base in the respective communities.

The main issues facing the territorial communities of Ukraine today are depreciation of infrastructure 
and the need to repair and reconstruct the premises of the socio-cultural sphere, to equip recreation and leisure, sports grounds, to organize cemeteries, to organize water supply, to improve the improvement of villages by improving the culture of domestic waste management, implementation of energy efficiency measures, access to the Internet. However, there are few active self-government bodies that are ready to engage in business to implement social projects. An example is the Zdolbunivsky District State Administration, which for the improvement of the territories accountable to it during 2011-2015 provided 200 thousand UAH from the rayon budget on terms of co-financing in equal parts by the relevant territorial community, where the maximum amount of the project is set at 15 thousand UAH. Selection of projects for financing initiated by local residents and businesses was conducted on a competitive basis. In 2016, it was foreseen to allocate 300 thousand UAH from the rayon budget, provided that at least $30 \%$ of the cost of the project (determined by the winner of the competition) was co-financed by the territorial community.

Taking into account the abovementioned, tax increment financing in Ukraine, in order to solve the problems of the development of territorial communities and the implementation of local initiatives, is a promising instrument. Self-governing bodies, acting as project initiators, will be able to attract additional financial resources from the central budget or from private investors to the development and improvement of their territory, having adopted for the financial base the income from the tax on property. However, in Ukraine, the basis for paying property taxes is not related to the value of the property but depends on its physical size and area, which uniquely differentiates the approach with the experience of the countries described above. Local governments, ensuring the development of local infrastructure, are interested in creating a new housing stock, timely putting it into the ration, having in its structure a certain share of dwellings with large areas (which will increase the tax base) and business property. However, given that in Ukraine, there is no clear correlation between the level of development of local infrastructure and the volume of income tax revenues, more dependence on the quantity and quality of residential and business development, creation of new workplaces on the territory is appropriate (in preparing the institutional environment for engagement financial and legal instruments for the development of territories), it is methodologically counted not only to the tax on the property but also to the increase of taxes on the income of the physical axes to the increase of taxes (because of more jobs) and single tax (due to increased business activity in the region). Further use in Ukraine of this method of financing infrastructure projects and the possibility of its impact on regional tax base will require the development of guidance and methodological framework for the implementation of this method, including mechanisms for providing and transfer of funds, method of calculation of future tax revenue guarantees for such projects to all stakeholders, Treasury services for such projects, etc. These aspects will be the subject of our further research on the impact of tax revenues on the financial capacity of territorial communities.

\section{Conclusions}

The most important self-financing resource of local authorities should be tax revenues in order to ensure that fiscal decentralization is sufficient. An intermediate result of the reform of the financial provision of local self-government is the structural change in tax revenues of local budgets. The main budget-forming tax in local budgets remains the income tax of individuals, and the transition to direct intergovernmental relations with the central budget of the combined territorial communities allows them to keep them at the disposal of $60 \%$ of the personal income tax, which will help to strengthen its own financial base exactly the administrative-territorial unit where the tax is charged and paid.

For a long time, budget-forming local tax remained a single tax for small businesses, whose revenues depend on the level of development of the business sector in a particular region. Therefore, this tax is an incentive for local governments to provide better conditions for living and doing business on the basis of economic and tax competition and, at the same time, a financial basis for the development of territorial communities.

Analysis of the structure of income tax revenues in the structure of tax revenues of local budgets shows that a large share of payments is provided by legal entities. We believe that in order to increase the share of tax revenues from individuals (the potential of this segment is still unrealized), an attention should be focused on improving the methodological basis for the calculation and collection of property taxes.

Although the structure of local budget revenues has undergone some changes, it did not contribute to a substantial strengthening of the material and financial base of local self-government bodies, the indicators of financial autonomy remain low and tax powers are insignificant. A promising method of state support for the development of territories is the tax increment financing, which will enable the region to attract capital and financial investments on a long-term basis. This will create the preconditions for creating a favourable investment climate, increasing the investment potential of territorial units in connection with the inflow of foreign and domestic investments, strengthening its own financial base of territorial communities, and will stimulate the effective use of internal social and economic potential. 


\section{References:}

On the Strategy of Sustainable Development "Ukraine-2020": Decree dated January 12, 2015 № 5/2015. URL: http://zakon5.rada.gov.ua/laws/show/5/2015

About the Principles of State Regional Policy: Law of Ukraine from 05.02.2015 № 156-VIII. URL: http://zakon3.rada.gov.ua/laws/show/156-19

On voluntary association of territorial communities: Law of Ukraine from 05.02.2015 № 157-VIII. URL: http://zakon2.rada.gov.ua/laws/show/157-19

On Approval of the Concept of Reforming Local Self-Government and Territorial Organization of Power in Ukraine: The Government of Ukraine, April 1, 2014 No. 333-p. URL: http://zakon2.rada.gov.ua/laws/show/ 333-2014-\%D1\%80

Kyrylenko, O., Malinyak, B., Luchka, A. \& Rusin, V. (2012). Improvement of resource provision and meeting of local budgets targets. Bulletin of the Ternopil National Economic University, 4, 36-46.

Krysovatyy, A. I. (Ed.). (2012). Regional Fiscal Policy: Theoretic Foundation and Practical Dominants of its Realization in Ukraine. Ternopil: TNEU. (in Ukrainian)

Lunina, I. O. (Ed.). (2010). Diversification of local government revenues. Institute of Economics and Forecasting. Kyiv. (in Ukrainian)

Storonyanska, I. Z. (2016). Prospects and risks of strengthening the financial capacity of territorial communities in the context of administrative-territorial reform in Ukraine. Economic Journal XXI, 11-12, 84-88.

Tarangul, L. L. (2015). Features of the formation of intergovernmental fiscal flows in the context of budget decentralization in Ukraine. Finance of Ukraine, 3, 30-44.

Yuriy, S. I. (2004). Financial paradigm of local self-government. The world of finance, 1, 6-14.

On Amendments to the Tax Code of Ukraine and certain Laws of Ukraine on Tax Reform: Law of Ukraine, December 28, 2014 No. 71-VIII. URL: http://zakon2.rada.gov.ua/laws/show/71-19

Recommendation Rec (2000). 14 of the Committee of Ministers to member states on local taxation, financial equalisation and grants to local authorities. URL: https://localgovernment.gov.mt/en/DLG/Legislation/ Documents/Legislation/R(2000)14.pdf

Decentralization. Local budgets of 159 territorial communities for 2016 year. (2016). Analytical materials. The Government of Ukraine. URL: http://www.minregion.gov.ua/wp-content/uploads/2017/04/ De-centr_297x210_April-2017.pdf

OECD (2011). Environmental Taxation. A Guide for Policy Makers. URL: https://www.oecd.org/env/toolsevaluation/48164926.pdf

Tax Code of Ukraine (2010). URL: http://zakon3.rada.gov.ua/laws/show/2755-17

Dye, R. \& Merriman, D. (2006). Tax Increment Financing. Tool for local Economic Development. URL: http://www.lincolninst.edu/publications/articles/tax-increment-financing

Halvin, M. (2013). Maine Voices: TIF helps communities that don't need it: State economic development support should go to towns that can't now take advantage of complex property tax schemes. Hampton, Maine: Portland Press Herald. URL: http://www.pressherald.com/2013/05/26/tif-helps-communities-that-dont-need-it_2013-05-26/ Stephens, R. \& Kille, L. W. (January 29, 2015). Urban regeneration: What recent research says about best practices. Harvard Kennedy School's Shorenstein Center and the Carnegie-Knight Initiative. Journalists Resource. URL: https://journalistsresource.org/studies/government/municipal/legacy-cities-challenges-opportunitiesurban-regeneration

Hardy, M., Lousyd, Tompagenet and others (2016). Tax increment financing. URL: https://www.coalitionforalivablecityvt.org/wp-content/uploads/2016/10/Tax-increment-financing.pdf Self-organization of the population - the way to the development of territorial communities. Zdolbuniv government (2016). Official portal. URL: http://zdolbun.gov.ua/samoorganizatsiya-naselennya-shlyah-do-ro/

OECD Fiscal Decentralization Database. URL: http://www.oecd.org/tax/federalism/fiscal-decentralizationdatabase.htm

Official site of the Treasury of Ukraine. Budget implementation. URL: http://www.treasury.gov.ua/main/uk/ doccatalog/list? currDir=146477 